\section{Die arkvaarders.}

Anne Provoost (vertaal deur Daniel Hugo). Pretoria: Protea Boekhuis, 2012. 311 pp. ISBN: 978-1-86919-461-1.

DOI: http://dx.doi.org/10.4314/tvl.v49i2.15

Die Belgiese skrywer, Anne Provoost, debuteer in 1991 met die roman Mijn tante is een grindewal waarvoor beide die Boekenleeuw en die Internasionale Prys vir Jeugliteratuur aan haar toegeken word. Haar werk is al in agtien tale vertaal. Provoost is ook 'n lid van die Koninklike Akademie vir Nederlandse Taal- en Letterkunde. Haar vierde roman, De arkvaarders, verskyn oorspronklik in 2001 in Nederlands. Die roman is intussen in sewe tale (insluitend Afrikaans) vertaal en het ook 'n aantal letterkundepryse verower naamlik die Boekenwelp en De Gouden Zoen-prys en is in 2006 ook vir die IMPAC Dublin internasionale toekenning genomineer.

Die arkvaarders kan geklassifiseer word as 'n historiese allegoriese roman wat gebaseer is op die verhaal van die sondvloed in Genesis 6-9. Die Bybelse karakters Noag en sy drie seuns Sem, Gam en Jafet speel 'n prominente rol in Provoost se roman. Anders as die tradisionele Bybelverhaal, word die verhaal van die sondvloed vanuit die eerstepersoonsperspektief vertel deur ReJana, 'n jong meisie wat saam met haar gesin na die woestynagtige gebied reis waar Noag en sy seuns die ark oprig. Die eerstepersoonsperspektief lei tot ' $n$ meer outentieke en realistiese inslag deurdat die verhaal van die sondvloed op 'n meer menslik georiënteerde wyse aan die hedendaagse leser oorvertel word.

ReJana se waarnemings van die gebeure voor, tydens en na afloop van die sondvloed verleen aan die tradisionele Bybelverhaal ' $n$ meer menslike element deurdat ReJana fokus op die ervarings en gevoelens van die nieuitverkorenes wat onder die valse indruk verkeer dat hulle ook deur Noag gered sou word indien hulle hom met die bou van die ark help. Ten spyte hiervan hou Noag, na wie deurentyd as "die boumeester" verwys word, voet by stuk dat "die onheil self die waarskuwing [is]" (185) en dat niemand deur middel van die vrees vir die dood God se plan om die mensdom weens hul sedelose lewenswyse uit te wis, van stryk sal laat bring nie. Hul hulp met die bou van die ark sal hulle gevolglik nie kan red nie. Hierdie standpunt wat "die boumeester" inneem, beeld hom gevolglik as ' $n$ hartelose en onvergewensgesinde karakter uit. Die hedendaagse leser kry gevolglik ' $n$ ander perspektief van Noag en sy seuns as in die Bybel waarin hulle as God se uitverkorenes byna bomenslike figure word. By die hedendaagse leser lei dit tot' $n$ minder simpatieke siening van die Bybelfigure wat deels toegeskryf kan word aan die wyse waarop Noag en sy seuns met die gewone mense omgaan.

Die roman het reeds voor sy verskyning kritiek vanuit talle oorde insluitende die Christen- en Moslemgemeenskappe uitgelok weens die onsimpatieke wyse waarop die Bybelkarakters deur Provoost uitgebeeld word. Die roman word selfs vanuit sommige oorde as godlasterlik beskryf aangesien Noag deur sowel die Christen- as die Islamgeloof as 'n heilige figuur beskou word. Elke leser moet egter self besluit vanuit watter perspektief hy of sy die roman wil benader. Provoost streef daarna om die verhaal vanuit ' $n$ ander perspektief as dié van die Bybel aan die leser oor te dra. Die arkvaarders slaag daarin om die leser uit te daag om dieper na te dink oor die menslike aspekte van die sondvloed en of dit inderdaad geregverdigde optrede teenoor die nie-sondige mense was. Provoost se roman sal egter nie deur alle lesers as godlasterlik beskou word nie aangesien dit bloot sekere kwessies uitlig wat die leser in staat stel om die sondvloed vanuit 'n meer menslike perspektief te benader.

Provoost se uitbeelding van Noag en sy seuns is realisties aangesien hulle van vlees en bloed was-mense wat seksuele drange 
gehad het en dié drange ook uitgeleef het. Aspekte soos ReJana se lesbiese verhouding met Gam se vrou, Neelata, die suggestie dat Noag aan 'n geslagsiekte gely het, die verkragting van ReJana se verlamde moeder asook die geweld en seks in die roman word op 'n uiters subtiele manier aangebied. Provoost beeld hierdie gebeure op' $n$ niegrafiese wyse uit wat 'n balans tussen die sosiale kwessies en die godsdienstige aspekte van die roman skep.

Daniel Hugo se keurige vertaling van die roman in Afrikaans sorg vir 'n boeiende leeservaring. Die roman slaag daarin om meer as net 'n storie te vertel. Die leser sal na afloop van die lees van die roman talle vrae oor die sondvloed hê wat tot vele gesprekke en verdere leeswerk of navorsing aanleiding kan gee. Die arkvaarders word ten sterkste aanbeveel vir diegene wat die sondvloed vanuit'n meer hedendaagse perspektief wil beskou. Menige leser sal hulle met ReJana se karakter kan vereenselwig en die verhaal van Noag se ark word op 'n veel dieper vlak as bloot 'n "oulike" Bybelstorie oor diere en reenboë oorvertel. Die arkvaarders is'n uiters geslaagde en relevante eietydse hervertelling van die eeue-oue Bybelverhaal.

Dewald Koen

koendewald@yahoo.com

Kingswood College

Grahamstad 